\title{
RETIRED GOVERNMENT OFFICIALS ON THE BOARD OF COMMISSIONERS AND TAX AGGRESSIVENESS IN INDONESIA
}

\author{
Riko Riandoko ${ }^{1)}$, Irwan Aribowo ${ }^{2 *}$, Zulfa Royani ${ }^{3)}$ \\ 1) riandoko@pknstan.ac.id, Polytechnic of State Finance STAN \\ 2) irwan aribowo@pknstan.ac.id, Polytechnic of State Finance STAN \\ 3) zulfa.royani@pajak.go.id, Polytechnic of State Finance STAN
}

\begin{abstract}
This study aims to determine the effect of retired government officials on board of commissioners on corporate tax aggressiveness. The presence of retired government officials on board of commissioners is assessed by categorizing companies into three groups: the company without any retired government officials on board of commissioners, the $\mathrm{c}^{1}$ ompany with one retired government official on board of commissioners, and the company with more than one retired government officials on board of commissioners. Corporate tax aggressiveness is measured using effective tax rate (ETR). The analysis is conducted on 441 observation data generated using purposive sampling for all the listed company on the Indonesia Stock Exchange in the period of 2014 to 2016. The results reveal that relative to there being one retired government official on the board of commissioners, greater than one retired government official presence on the board of commisioners does not reduces corporate tax aggressiveness.
\end{abstract}

Keywords: tax aggresiveness, effective tax rate, retired government officials, board of commissioners

\section{INTRODUCTION}

In the past five years, Indonesia has been categorized into lower middle income countries with low tax ratio (tribunnews.com). Quoted from wartaekonomi.co.id, Finance Minister Sri Mulyani said Indonesia's tax ratio is at $11 \%$ level. According to members of Commission XI of the House of Representatives Misbakhun in tribunnews.com, this figure is below the average tax ratio of lower middle income countries which reached 17.7\%. Director of Tax Regulation II DJP John Hutagaol revealed, this low tax ratio indicates the low public awareness in paying taxes. This can be seen from the total comparison between the amount of taxes that have been levied with the tax potential ratio that can only be taxed (tax coverage ratio) which only reached $55 \%$, far from the maximum figure of $70 \%$ (okezone.com).

In the Ministry of Finance website mentioned that tax revenue is still the largest contributor with an average contribution of $77.6 \%$ of revenues of the state budget. For the state, taxes are an important revenue source that will be used to finance state expenditures. In contrast, for firms, taxes are a material cost component of financial statements (Dyreng et. al., 2008). Recent evidence shows that managerial actions designed solely to minimize corporate taxes through tax aggressive activitiesare becoming an increasingly common feature of the corporate landscape in many countries around the world (Lanis dan Richardson, 2011).

Desai and Dharmapala (2006) consider the association between corporate governance and tax aggressiveness within the agency framework. Good corporate governance can have a positive impact to company's compliance of tax regulation (Wahyudi, 2014). The Internal Revenue Service (IRS) has suggested that good corporate governance practices, including adequate tax risk management, are necessary to reduce tax aggressiveness. (Lanis et. al., 2015).

Different from that other governance mechanisms, the structure of the board of directors has an important role to play in monitoring management (Uzun et. al., 2004). Indeed, Fama and Jensen (1983) argue that the board is a major internal control mechanism, which is responsible for 


\section{EDUCORETAX}

Volume 1 No. 4, Desember 2021

monitoring the equity of management. Recently, Lanis and Richardson (2011) show that the inclusion of a higher proportion of outside members on the board of directors reduces the likelihood of tax aggressiveness.

An important corporate governance mechanism in Japan is former government officials who, after retirement from long years of civil service, is reemployed as director or commisioner in the private companies (Schaede, 1994). It is consistent with findings that former government officials are increasingly sought after for America's corporate board rooms (Korn, 2000). In Indonesia, it is also common to find ex-government officers serving in the board of commissioners (Hidayat and Utama, 2016). Quoted from page detik.com, President Director of BEI Tito Sulistio stated that the military generals and former government officials in the board of commissioners assist the implementation of corporate governance because of their experience.

Retired government officials might be appointed as directors because of their experiences and contacts in working with government agencies (Latif et. al., 2013). Then, Latif et. al. (2013) argue that retired government officials on boards could lead to better decision making and increased the performance of the companies. The depth and breadth of human and social capital embodied in each director candidate is an important determinant of his or her attractiveness as an outside director (Lester et. al., 2008).

Johnson (1974) stated that the re-employment of retired government officials as member of board by private enterprise in Japan began as a largely ad-hoc process in response to very real needs of businesses and bureaucrats. Schaede (1995) stated that former government officials who serve as the board of directors in Japan, are able to smoothen the information flow between government and business. They impact the formulation of corporate strategies in accordance to government regulations (Schaede, 1995), including tax law.

Contrary to the phenomenon, PT Ace Hardware Indonesia Tbk. (ACES) and PT Astra International Tbk. (ASII), which have retired government officials in board of commissioner, actually indicates the behavior of tax aggressiveness. This can be seen from the average effective tax rate (ETR) which is below the 25\% corporate tax rate in 2012 to 2016 (Figure 1). In addition, ACES has an ETR below the average ETR of retail companies. ETR ACES is also lower than companies that do not have a retired government commissioner, PT Erajaya Swasembada Tbk. (ERAA) and PT Tiphone Mobile Indonesia Tbk. (TELE). Similarly in automotive companies, ASII has an ETR below the average ETR of automotive companies. ETR ASII is also lower than companies that do not have a commissioner of retired government officials, namely PT Nipress Tbk. (NIPS) and PT Selamat Sempurna Tbk. (SMSM).

The existence of retired government officials in board can coordinate the company's business relationship with the government. Companies should not engage in aggressive tax activities. However, the reality is that there are companies with former government officials as commissioners who engage in tax aggressiveness. Through this research, we try to find out whether and how the relationship between retired government officials in the board of commissioners toward tax aggressiveness. 


\section{EDUCORETAX}

Volume 1 No. 4, Desember 2021

Figure 1

Comparison of ETR of Retail and Automotive Companies

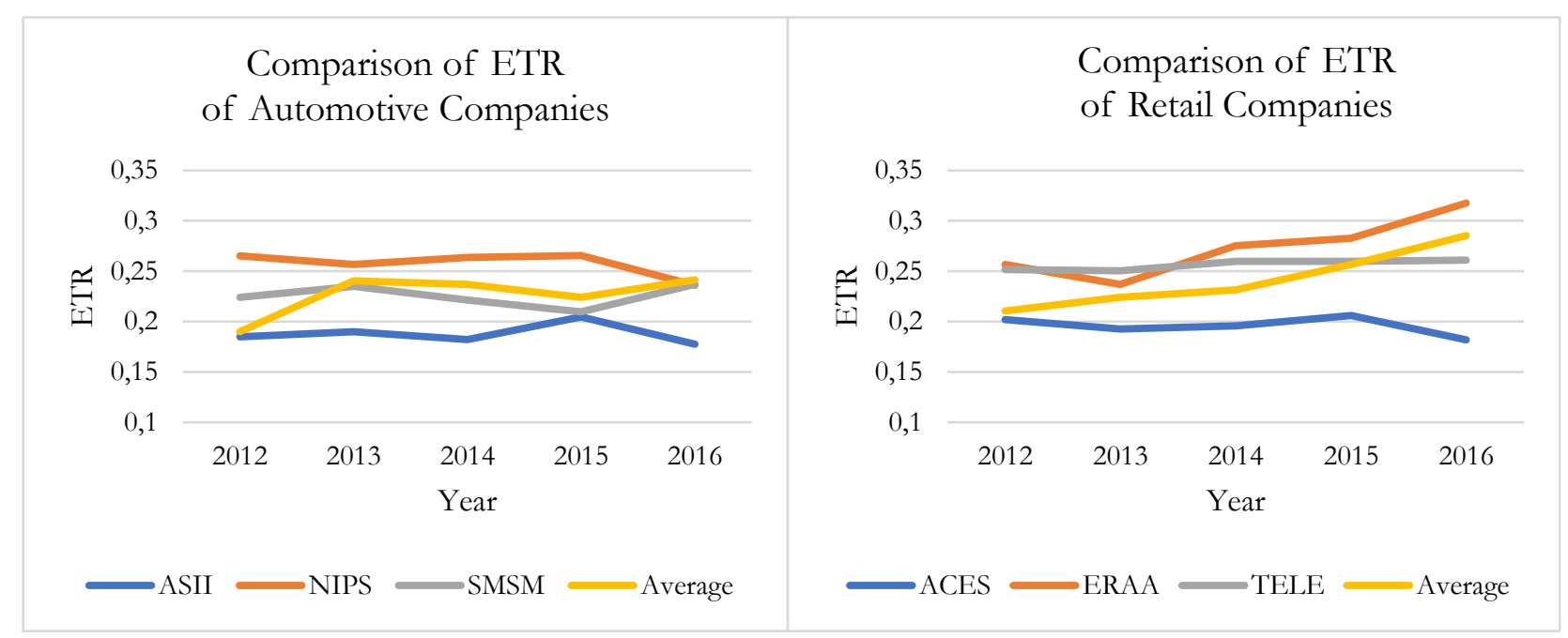

Employing a sample of 147 publicly-listed Indonesian firms over the 2014-2016 period (441 firm-years), our regression results show that relative to there being one retired government official board member, high (i.e., greater than one member) retired government official presence on that board of commisioners do not reduces the likelihood of tax aggressiveness.

Our study is the first to provide empirical evidence concerning the association between the presence of retired government officials on the board of commissioners and tax aggressiveness. Thus, our study extends the extant literature on corporate governance and tax aggressiveness. Finally, our research is timely since there has been increased pressure by government bodies in Indonesia and globally to develop policies about retired government official representation on the board.

The paper is organized as follows. Section 2 considers the literature review of this study and develops our hypothesis. Section 3 presents the research methodology. Section 4 reports the empirical results. Finally, Section 5 provides the concluding remarks.

\section{LITERATURE REVIEW}

\section{Board of Commissioners and Corporate Governance}

In terms of corporate governance, Indonesia regulation distinguished board of commissioners and the board of directors. Based on Law No. 40 Year 2007 regarding Limited Liability Company, the board of directors is the part of the company's authorized and fully responsible for the management for the benefit of the organization, in accordance with the company's purposes and objectives and to represent the company. Meanwhile, the board commisioners is the part of the organization that in charge of supervising the organization and provide advice to the board of directors.

The board accepts the ultimate responsibility for the tax affairs of the firm and is held accountable for them by the firm's shareholders (Erle, 2008). Landolf (2006) argues that as the risks faced in tax matters have become more diverse, the board must, within the framework of the risk management strategy of the firm, participate more in the firm's tax policy and strategies. The board of directors is chiefly responsible for monitoring the behavior of management (Fama and Jensen, 1983). Prior research has studied the impact of board monitoring on the likelihood of 


\section{EDUCORETAX}

Volume 1 No. 4, Desember 2021

financial reporting and corporate fraud (Beasley, 1996) in addition to tax aggressiveness (Lanis and Richardson, 2011). Richardson et. al (2013) conducted research on the characteristics of the board of commissioners towards aggressive corporate tax. The results showed that the characteristics of the supervisory board of commissioners affect the level of tax aggressiveness.

\section{Retired Government Officials as Outside Board Candidates}

An assumption of previous governance research is that individual who appointed in the board is expected to support the organization, will concern himself with its problems, will variably present it to others, and will try to aid it (Pfeffer \& Salancik, 1978: 163). Hillman (2005) argued that the four general benefits derived from directors identified by Pfeffer and Salancik (1978) also apply to the specific context of government officials as directors. This research stated that government officials can provide valuable advice and counsel regarding the public policy environment of a firm; channels of communication to existing government officials, bureaucrats, and other political decision makers; influence over political decisions; and legitimacy. Hillman's (2005) empirical findings support the notion that firms with government officials on their boards enjoy better financial performance than those lacking such directors.

The government has long been recognized as an important source of dependence for companies (Pfeffer dan Salancik, 1978). Nearly every aspect of business is shaped by government regulation, which can significantly modify firms' opportunity sets. (Lester et. al., 2008). Government policy can affect the competitive positions of firms and influence their future performance by changing the size of markets, establishing entry and exit barriers, providing special tax or subsidy treatments, and altering firm costs through legislation on employment, safety, or environmental protection standards (Gale dan Buchholz, 1987; Shaffer, 1995 dalam Lester et. al., 2008).

Given firms' dependency on government, it is not surprising that many have sought to form links with the government through their boards (Lester et. al., 2008). In terms of taxation, political connection through independent commissioners has negative impact to tax aggresiveness (Pranoto and Widagdo, 2016). Thus, it is reasonable to expect that retired government official presence on the board of commissioners could significantly reduce the likelihood of tax aggressiveness. Thus, our study tests the following hypothesis:

H1: Assuming other factors remain constant, relative to the presence of a retired government officials in board of commisioners, there is a negative correlation between the presence of more than one retired government officials in board of commisioners towards the aggressiveness of corporate taxes.

\section{METHODOLOGY}

\section{Sample selection and data}

Our sample initially consisted of 441 Indonesian publicly-listed firms for the year of 2014 to 2016. However, we excluded from our sample which fall into the following categories: firms that belong to financial sector; firms with negative or more than one ETR; firms with majority of income are subjected to final income taxes; and firms with incomplete data variables studied. Finally, all data were collected from the financial and annual reports of the sample firms.

\section{Dependent Variable}

The dependent variable is the corporate tax aggressiveness that measured directly from the company's financial statements. Tax aggressiveness (TA) measurement uses Effective Tax Rates (ETR). ETR is measured by comparing the income tax expense to pre-tax income (Gupta and Newberry, 1997). The high ETR indicate the lower tax aggressiveness. To explain the relationship 


\section{EDUCORETAX}

Volume 1 No. 4, Desember 2021

of dependent variable and independent variables, the figures from the ETR calculation is multiplied by -1 to indicate an increase in the size of the tax aggressiveness (Lanis \& Richardson, 2012).

\section{Independent Variable}

The independent variable is the presence of retired government officials in board (PRGOBOD). A board member can be categorized as an ex-government officer if he has served as a central government officer (minister, house of representative), local government officer (governor), in the military forces (national army), or as a government organization head (Hidayat and Utama, 2016).

The independent variable will then be subdivided into three major parts, PRGOBODNONE with no retired government officials on the board, PRGOBODMOD with one retired government officials on board, PRGOBODHIGH with more than one retired government officials on board. This 3 is a dummy variable. PRGOBODNONE coded 1 if there are no retired government officials on the board, besides 0 . PRGOBODMOD coded 1 if there are one retired government officials on the board besides 0. PFEMBODHIGH coded 1 if there are more than one retired government officials on the board of commissioners in addition to the 0 .

\section{Control Variables}

Control variables is described as follow:

a. BODIND is a variable to see the difference of supervisory capacity and incentives depending on the proportion of independent directors (Fama \& Jensen, 1983). BODIND is a dummy variable, coded 1 if the firm has more than $70 \%$ independent directors on boards of trustees, besides 0 .

b. AGEDIR is a variable to describe the average age of the board. This variable is used to see if the commissioner has adequate professional capability to supervise the company (Carter, D'Souza, Simkins, \& Simpson, 2010). The Company supervised by a person who has ability and professional experience will tend not to perform tax aggressiveness. AGEDIR measured by averaging the age of its commissioners.

c. BIG4AUD is a variable to see the difference between the four major auditors with others (Matsumura \& Tucker, 1992). Companies audited by one of the four major auditors have a tendency not to perform tax aggressiveness. BIG4AUD is a dummy variable, which was given the code 1 if the company uses one of the four major auditors as external auditors, besides 0 .

d. BLOCK is a variable to see the effect of significant shares ownership of the company to oversee the board. Shareholders with significant ownership will help the company because they have a greater influence on the board compared to the other shareholders (Shleifer and Vishny, 1986). BLOCK measured by total proportion of shares owned by shareholders who have ownership of at least $5 \%$ of the shares outstanding and unrelated to management.

e. FSIZE is the variable that describes the influence of company size on the tax aggressiveness. The larger company can achieve a greater degree of economy through tax planning actions (Rego S., 2003). FSIZE measured by the natural logarithm of total assets.

f. LEV is the variable to see the trend of the high debt that reduce of corporate taxes. The higher the debt to equity ratio (DER) indicates a more efficient company in reducing corporate taxes (Gupta and Newberry, 1997). LEV is measured by comparing the long-term debt to total assets.

g. CAPINT and INVINT describe the behavior of companies regarding the recognition of accelerated depreciation and inventory recognition of the tax year. CAPINT positively associated on tax aggressiveness through accelerated tax depreciation charged to the current year. INVINT negatively associatied on tax aggressiveness through the recognition of inventory in the current year (Stickney and McGee, 1982). CAPINT is measured by dividing 


\section{EDUCORETAX}

Volume 1 No. 4, Desember 2021

the net property, plan, and equipment with total assets while INVINT measured by dividing inventory by total assets.

h. RDINT serve as one of the variables that related positively with the tax aggressiveness (Gupta and Newberry, 1997). The higher the amount of expenditure for the purpose of research and development indicates the tax aggressiveness. RDINT is measured by dividing the R \& D expenditure in total assets.

i. THAV is variable to see if the company has a relationship such as the existence of subsidiaries in countries belonging to the OECD list of tax haven countries. The use of tax haven countries is positively associated with tax aggressiveness (Desai, Foley, \& Ilines, 2006). THAV is dummy variable, coded 1 if the company has subsidiaries in tax haven countries, besides 0 .

j. MBK is variable that describe the company's value growth opportunities (Gupta and Newberry, 1997). MBK is measured by comparing the market price and the book value of the equity.

$\mathrm{k}$. ROA is the controlling variable to describe the company's operating performance (Gupta and Newberry, 1997). ROA is calculated by dividing income before tax on total assets.

1. INDS is a dummy variable to determine the classification of the company in accordance groupings used by the Stock Exchange listed companies as regulatory authorities in Indonesia. Industrial classification used in this study is JASICA (Jakarta Stock Exchange Industrial Classification). Industrial sector classification used are: agriculture, mining, chemical and basic industry, various industries, consumer goods industry, property and real estate, transportation and infrastructure, and trade and services. Code 1 INDS controlling variable is given if the company categorized as one of the industry classification JASICA, besides 0 . This code is the controlling variable that describes the tax aggressiveness.

$\mathrm{m}$. YR is a variable for controlling the differences regarding potential tax aggressiveness occurred during the years of research, from 2014 to 2015. YR is a dummy variable, coded 1 in the event of related tax aggressiveness during the research period.

\section{Regression Model}

This research applies a model similar as Richardson et. al. (2016) with some adjustments:

$$
\begin{aligned}
& T A_{i t}=\alpha_{0}+\beta_{1} \text { PRGOBODNONE } E_{i t}+\beta_{2} \text { PRGOBODHIGH } H_{i t}+\beta_{3} \text { BODIND }_{i t}+\beta_{4} A G E D I R_{i t} \\
& +\beta_{5} B I G 4 A U D_{i t}+\beta_{6} B L O C K_{i t}+\beta_{7} \text { FSIZE }_{i t}+\beta_{8} L E V_{i t}+\beta_{9} C A P I N T_{i t} \\
& +\beta_{10} I N V I N T_{i t}+\beta_{11} R D I N T_{i t}+\beta_{12} T H A V_{i t}+\beta_{13} M B K_{i t}+\beta_{14} R O A_{i t} \\
& +\beta_{15-20} I N D S_{i t}+\beta_{21-22} Y R_{i}+\varepsilon_{i t}
\end{aligned}
$$

where $\mathrm{i}=$ firms $1-441 ; \mathrm{t}=$ financial years 2014-2016; TA $=-$ ETR; PRGOBODNONE $=$ a dummy variable, coded 1 if there is no retired government officials on the board, otherwise 0 ; PFEMBODHIGH $=$ a dummy variable, coded 1 if there is more than one retired government officials on the board, otherwise $0 ;$ BODIND $=$ a dummy variable, coded 1 if the firm has a board of directors which is largely $(>70 \%)$ made-up of independent directors, otherwise 0; AGEDIR = the average age of directors serving on the board; BIG4AUD $=$ a dummy variable, coded 1 if the firm uses a big four external auditor, otherwise 0 ; BLOCK $=$ the total proportion of ordinary share capital of blockholders who hold at least five\% of outstanding shares and are not affiliated with management; FSIZE = natural logarithm of total assets; LEV = long-term debt scaled by total assets; CAPINT = net property, plant and equipment scaled by total assets; INVINT = inventory scaled by total assets; RDINT $=$ R\&D expenditure scaled by total assets; THAV = a dummy variable, coded 1 if the firm has at least one subsidiary company incorporated in an OECD (2006) listed tax haven, otherwise $0 ; \mathrm{MBK}=$ the market value of equity scaled by the book value of equity; $\mathrm{ROA}=$ pre-tax income scaled by total assets; INDS = industry sector dummy variable, coded 1 if 


\section{EDUCORETAX}

Volume 1 No. 4, Desember 2021

the firm is represented in the particular JASICA category, otherwise 0; YR = year dummy variable, coded 1 if the year falls within the specific year category, otherwise 0 ; and $\varepsilon=$ error term.

\section{EMPIRICAL RESULT \\ Descriptive Statistics}

The descriptive statistics are reported in Table 1. For the dependent variable (TA), sample firms have a mean TA of approximately $-27.8 \%$. In terms of the independent variables, sample firms have a mean PRGOBODNONE, PRGOBODMOD and PRGOBODHIGH of 56\%, 26.8\%, and $17.2 \%$, respectively. The mean, standard deviation, median, and range of the control variables are also summarized in Table 1.

Table 1

Descriptive Statistics

\begin{tabular}{lccccc}
\hline \multicolumn{1}{c}{ Variable } & Mean & Std. Dev & Minimum & Median & Maximum \\
\hline TA & -0.278 & 0.125 & -0.937 & -0.254 & -0.017 \\
PRGOBODNONE & 0.560 & 0.497 & 0.000 & 1.000 & 1.000 \\
PRGOBODMOD & 0.268 & 0.443 & 0.000 & 0.000 & 1.000 \\
PRGOBODHIGH & 0.172 & 0.378 & 0.000 & 0.000 & 1.000 \\
BODIND & 0.016 & 0.125 & 0.000 & 0.000 & 1.000 \\
AGEDIR & 58.591 & 6.692 & 33.500 & 58.667 & 79.000 \\
BIG4AUD & 0.472 & 0.500 & 0.000 & 0.000 & 1.000 \\
BLOCK & 0.690 & 0.170 & 0.111 & 0.684 & 0.994 \\
FSIZE & 28.717 & 1.614 & 24.568 & 28.693 & 33.199 \\
LEV & 0.147 & 0.128 & 0.005 & 0.100 & 0.611 \\
CAPINT & 0.356 & 0.207 & 0.007 & 0.322 & 0.906 \\
INVINT & 0.170 & 0.139 & 0.000 & 0.154 & 0.614 \\
RDINT & 0.001 & 0.004 & 0.000 & 0.000 & 0.037 \\
THAV & 0.032 & 0.176 & 0.000 & 0.000 & 1.000 \\
MBK & 2.989 & 5.807 & 0.111 & 1.649 & 62.931 \\
ROA & 0.106 & 0.091 & 0.000 & 0.084 & 0.580 \\
\hline
\end{tabular}

Refer to Equation 1 for variable definitions.

$\mathrm{N}=441$ for all variables.

\section{Correlation Result}

Table 2 presents the Pearson pairwise correlation results. We find significant positive correlations between TA and PRGOBODHIGH ( $p$-value <0.05). We also find significant correlations between TA and several control variables ( $p$-value $<0.10$ or better with predicted signs). 


\section{EDUCORETAX}

Volume 1 No. 4, Desember 2021

Table 2

Pearson Pairwise Correlation Result

\begin{tabular}{|c|c|c|c|c|c|c|c|c|c|c|c|c|c|c|c|c|}
\hline & 1 & 2 & 3 & 4 & 5 & 6 & 7 & 8 & 9 & 10 & 11 & 12 & 13 & 14 & 15 & 16 \\
\hline $1 \mathrm{TA}$ & 1 & & & & & & & & & & & & & & & \\
\hline 2 PRGOBODNONE & -0.054 & 1 & & & & & & & & & & & & & & \\
\hline 3 PRGOBODMOD & -0.037 & -0.682 *⿰冫欠 & 1 & & & & & & & & & & & & & \\
\hline 4 PRGOBODHIGH & $0.115^{\text {** }}$ & $-0.515^{* ⿰ \alpha \times}$ & -0.276 *⿰冫中⿰㇀丶㇀ & 1 & & & & & & & & & & & & \\
\hline 5 BODIND & 0.032 & 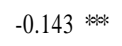 & 0.005 & 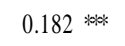 & 1 & & & & & & & & & & & \\
\hline 6 AGEDIR & 0.066 & -0.190 wow & 0.148 * *opk & 0.076 & 0.029 & 1 & & & & & & & & & & \\
\hline 7 BIG4AUD & $0.104^{* *}$ & -0.114 * * & -0.068 & 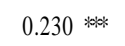 & 0.098 ** & 0.013 & 1 & & & & & & & & & \\
\hline 8 BLOCK & 0.051 & -0.030 & 0.115 * & -0.095 炏 & -0.036 & -0.024 & 0.047 & 1 & & & & & & & & \\
\hline 9 FSIZE & 0.063 & $-0.253 * * \%$ & 0.002 & $0.330 * \%$ & 0.038 & 0.043 & 0.517 & $-0.134 * * *$ & 1 & & & & & & & \\
\hline $10 \mathrm{LEV}$ & -0.042 & -0.025 & 0.012 & 0.019 & $-0.096 * *$ & 0.040 & 0.032 & $-0.134 * * \cdots$ & $0.327 * * *$ & 1 & & & & & & \\
\hline 11 CAPINT & $-0.193 * *$ & -0.057 & 0.001 & 0.074 & 0.101 * * & 0.045 & -0.027 & 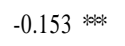 & 0.105 ** & $0.240 *$ * & 1 & & & & & \\
\hline 12 INVINT & 0.058 & 0.044 & 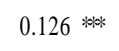 & 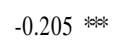 & -0.044 & -0.049 & -0.060 & 0.187 *ow & $-0.149 *$ * * & -0.372 炏氺 & $*-0.426$ * * * & 1 & & & & \\
\hline 13 RDINT & 0.022 & $-0.095 *$ & -0.030 & $0.160^{\text {*opk }}$ & -0.024 & 0.038 & -0.028 & -0.048 & 0.031 & -0.110 ** & -0.071 & 0.070 & 1 & & & \\
\hline 14 THAV & -0.024 & -0.126 * * * & 0.037 & $0.123^{\text {*⿻丷木 }}$ & -0.023 & 0.031 & 0.192 & 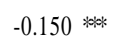 & 0.293 * *ak & 0.161 **⿰冫欠 & $* 0.033$ & $-0.094 * *$ & -0.034 & 1 & & \\
\hline $15 \mathrm{MBK}$ & $0.088 *$ & -0.222 *⿻大s & 0.008 & $0.283^{\text {*obk }}$ & 0.534 & 0.035 & 0.163 & $0.106 *$ & 0.150 * * o k & -0.046 & 0.078 & -0.021 & 0.034 & -0.039 & 1 & \\
\hline $16 \mathrm{ROA}$ & $0.257 * *$ & $-0.216^{* * \alpha k}$ & 0.008 & $0.274 * * 6 \%$ & 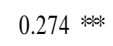 & 0.052 & 0.290 & $0.124 * * * k$ & $0.138 * * \alpha$ & -0.229 * & -0.067 & -0.011 & 0.069 & -0.038 & $0.664 * * 6 \%$ & 1 \\
\hline
\end{tabular}

$*, * *$, and $* * *$ indicate significance at the $0.10,0.05$, and 0.01 levels.

The $p$-values are one-tailed for directional hypothesis and two-tailed otherwise.

Refer to Equation 1 for variable definitions.

$\mathrm{N}=441$ for all variables. 


\section{EDUCORETAX}

Volume 1 No. 4, Desember 2021

\section{Regression Result}

Table 3

Regression Result

\begin{tabular}{|c|c|c|}
\hline Variable & Predicted Sign & Coefficient/(t-statistics) \\
\hline \multirow[t]{2}{*}{ Intercept } & $?$ & -0.356 \\
\hline & & $(-1.75) *$ \\
\hline \multirow[t]{2}{*}{ PRGOBODNONE } & $?$ & 0.007 \\
\hline & & $(0.41)$ \\
\hline \multirow[t]{2}{*}{ PRGOBODHIGH } & - & 0.039 \\
\hline & & $(1.71) * *$ \\
\hline \multirow[t]{2}{*}{ BODIND } & - & 0.005 \\
\hline & & $(0.08)$ \\
\hline \multirow[t]{2}{*}{ AGEDIR } & - & 0.000 \\
\hline & & $(0.03)$ \\
\hline \multirow[t]{2}{*}{ BIG4AUD } & - & 0.006 \\
\hline & & $(0.33)$ \\
\hline \multirow[t]{2}{*}{ BLOCK } & - & -0.020 \\
\hline & & $(-0.42)$ \\
\hline \multirow[t]{2}{*}{ FSIZE } & + & 0.003 \\
\hline & & $(0.47)$ \\
\hline \multirow[t]{2}{*}{ LEV } & + & 0.056 \\
\hline & & $(0.83)$ \\
\hline \multirow[t]{2}{*}{ CAPINT } & + & -0.078 \\
\hline & & $(-1.96) * *$ \\
\hline \multirow[t]{2}{*}{ INVINT } & - & -0.037 \\
\hline & & $(-0.55)$ \\
\hline \multirow[t]{2}{*}{ RDINT } & + & -0.884 \\
\hline & & $(-0.39)$ \\
\hline \multirow[t]{2}{*}{ THAV } & + & -0.020 \\
\hline & & $(-0.46)$ \\
\hline \multirow[t]{2}{*}{ MBK } & $?$ & -0.003 \\
\hline & & $(2.02) * *$ \\
\hline \multirow[t]{2}{*}{ ROA } & $?$ & 0.476 \\
\hline & & $(4.58) * * *$ \\
\hline INDS & $?$ & Yes \\
\hline YR & $?$ & Yes \\
\hline $\mathrm{R}^{2}(\%)$ & & 19.01 \\
\hline $\mathrm{N}$ & & 441 \\
\hline
\end{tabular}

The $p$-values are one-tailed for directional hypothesis and two-tailed otherwise. Refer to Equation 1 for variable definitions.

Table 3 reports the regression analysis results which consider the association between the presence of retired government officials on the board of commissioners and corporate tax 


\section{EDUCORETAX}

Volume 1 No. 4, Desember 2021

aggressiveness. We find that the regression coefficient for PRGOBODHIGH is significantly positively associated with TA ( $p$-value $<0.05$ ), providing do not support for H1. Accordingly, relative to there being one retired government official present on the board of commissioners, the presence of more than one retired government official member on that board increases the likelihood of tax aggressiveness. This result is not consistent with our expectation that firms which have relatively high (i.e., greater than one) retired government official presence on the board impact the formulation of corporate strategies in accordance to government regulations Moreover, there is no significant difference between the incidence of tax aggressiveness when there are no retired government official board representatives or when there is a single retired government official representative on the board. We also find that control variables pertaining to CAPINT, ROA, and MBK are significantly associated with TA ( $p$-value $<0.05$ or better with predicted signs) as reported in Table 3.

\section{CONCLUSION}

This paper examines the impact of retired government officials on the board of commisioners on corporate tax aggressiveness in Indonesia. Our regression results show that relative to there being one retired government official board member, high (i.e., greater than one member) retired government official presence on that board of commisioners do not reduces the likelihood of tax aggressiveness. The results of this study are not in line with the author's research hypothesis. More retired government officials in the board of commissioners actually make the aggressiveness of corporate tax increases.

This difference can be explained by several things. First, the recruitment of retired government officials as board of commissioners may not aim to support government programs or policies, but rather political lobbying. In Zhang et. al. (2012), the company makes use of political connections to lobby with the government to avoid tax audits, tax reduction fines, and other tax aggressiveness actions.

Second, a major difference between developed capitalisms and developing capitalisms is that the latter tend to be "relationship-based" or "crony" rather than "market-based" capitalisms (Rajan dan Zingales, 1998). Based on the research conducted by Adhikari et. al. (2006), there is a "relationship-based" capitalism in Malaysia. They find firms with political connections pay tax at significantly lower effective rates than other firms. The same study was conducted in Indonesia. Both of them concluded that firms with political connections pay lower effective rates than other companies (Adhikari, 2006 and Wicaksono, 2017). Political connections are often utilized to take advantage to obtain special treatment from governments in terms of taxation, such as avoiding tax audits (Adhikari, 2006). Thus "relationship-based" capitalism also occurs in Indonesia, where closeness to the government becomes one of the key factors in business. The company is trying to recruit more retired government officials to build business relationships with stakeholders. With the principle of crony capitalism, business success depends on the close relationship between businessman and government officials. Quoted from the cnnindonesia.com, Indonesia ranks seventh in the index of The Economist's 2016 Crony Capitalism. This position rises one rank from the previous year. This index indicates that some industries tend to rent through cartel, monopoly, and business lobby practices involving government officials.

Our study is the first to provide empirical evidence concerning the association between the presence of retired government officials on the board of commissioners and tax aggressiveness. Thus, our study extends the extant literature on corporate governance and tax aggressiveness. Finally, our research is timely since there has been increased pressure by government bodies in 


\section{EDUCORETAX}

Volume 1 No. 4, Desember 2021

Indonesia and globally to develop policies about retired government official representation on the board.

\section{REFERENCES}

Adhikari, A., Derashid, C., \& Zhang, H. (2006). Public policy, political connections, and effective tax rates: Longitudinal evidence from Malaysia. Journal of Accounting and Public policy, 25(5), 574-595.

Beasley, M. S. (1996). An Empirical Analysis of The Relation Between the Board of Director Composition and Fnancial Statement Fraud. The Accounting Review, Vol. 71 (4): 443-465.

Carter, D. A., D'Souza, F., Simkins, B. J., \& Simpson, W. G. (2010). The gender and ethnic diversity of US boards and board committees and firm financial performance. Corporate Governance: An International Review, 18(5), 396-414.

Desai, M. A., Foley, C. F., \& Hines Jr, J. R. (2006). The demand for tax haven operations. Journal of Public economics, 90(3), 513-531.

Desai, M. A., \& Dharmapala, D. (2006). Corporate tax avoidance and high-powered incentives. Journal of financial Economics, 79(1), 145-179.

Dyreng, S. D., Hanlon, M., \& Maydew, E. L. (2008). Long-run corporate tax avoidance. The accounting review, 83(1), 61-82.

Erle, B. (2008). Tax Risk Management and Board Responsibility, in Wolfgang Schön ed., Tax and Corporate Governance, Berlin Heidelberg, Springer-Verlag.

Fama, E. F., \& Jensen, M. C. (1983). Separation of ownership and control. The journal of law and Economics, 26(2), 301-325.

Gupta, S., \& Newberry, K. (1997). Determinants of the variability in corporate effective tax rates: Evidence from longitudinal data. Journal of accounting and public policy, 16(1), 1-34.

Hidayat, A. A., \& Utama, S. (2017). Board characteristics and firm performance: Evidence from Indonesia. International Research Journal of Business Studies, 8(3).

Hillman, A. J. (2005). Politicians on The Board of Directors: Do Connections Affect the Bottom Line? Journal of Management, Vol. 31: 464-481.

Johnson, C. (1974). The Reemployment of Retired Government Bureaucrats in Japanese Big Business. Asian Survey, Vol. 14, No. 11: 953-965.

Korn/Ferry International. (2000). Annual Report on Corporate Governance. New York: Korn/Ferry.

Landolf, U. (2006). Tax and Corporate Responsibility. International Tax Review, Vol. 29: 6-9.

Lanis, R., Richardson, G., \& Taylor, G. (2017). Board of director gender and corporate tax aggressiveness: An empirical analysis. Journal of Business Ethics, 144(3), 577-596.

Lanis, R., \& Richardson, G. (2011). The effect of board of director composition on corporate tax aggressiveness. Journal of accounting and Public Policy, 30(1), 50-70.

Latif, R. A., Kamardin, H., Mohd, K. N. T., \& Adam, N. C. (2013). Multiple directorships, board characteristics and firm performance in Malaysia. Management, 3(2), 105-111.

Lester, R. H., Hillman, A., Zardkoohi, A., \& Cannella Jr, A. A. (2008). Former government officials as outside directors: The role of human and social capital. Academy of Management Journal, 51(5), 999-1013.

Matsumura, E. M., \& Tucker, R. R. (1992). Fraud detection: A theoretical foundation. Accounting Review, 753-782.

Pfeffer, J. \& Salancik, G. (1978). The External Control of Organizations: A Resources Depedence Perspective. New York: Harper \& Row. 


\section{EDUCORETAX}

Volume 1 No. 4, Desember 2021

Pranoto, B. A., \& Widagdo, A. K. (2016). Pengaruh Koneksi Politik dan Corporate Governance Terhadap Tax Aggressiveness. Syariah Paper Accounting FEB UMS, 1(3), 472-486.

Rajan, R., \& Zingales, L. (1998). Which Capitalism? Lesson from the East Asian Crisis. Journal of Applied Corporate Finance, Vol. 11: 40-48.

Rego, S. O. (2003). Tax-Avoidance Activities of US Multinational Corporations. Contemporary Accounting Research, Vol. 20, No. 4: 805-833.

Richardson, G., Taylor, G., \& Lanis, R. (2013). The Impact of Board of Directors Oversight Characteristic on Corporate Tax Aggressiveness: An Empirical Analysis. Journal of Accounting and Public Policy, Vol. 32: 68-88.

Richardson, G., Taylor, G., \& Lanis, R. (2016). Women on the Boards of Directors and Corporate Tax Aggressiveness in Australia: An Empirical Analysis. Accounting Research Journal, Vol. 29.

Schaede, U. (1994). Understanding Corporate Governance in Japan: Do Clasical Concepts Apply? Industrial and Corporate Change, Vol. 3.

Schaede, U. (1995). The "Old Boy" Network and Government-Bussiness Relationship in Japan. The Journal of Japanese Studies, Vol. 21: 293-317.

Shleifer, A. \& Vishny, R. W. (1986). Large Shareholders and Corporate Control. Journal of Political Economy, Vol. 95: 461-488.

Stickney, C. \& McGee, V. (1982). Effective Corporate Tax Rates: The Effect of Size, Capital Intensity, Leverage, and Other Factors. Journal of Accounting and Public Policy, Vol. 1, No. 2: 125-152.

Uzun, H., Szewczyk, S. H., \& Varma, R. (2004). Board Composition and Corporate Fraud. Financial Analysts Journal, Vol. 60, No. 3, 33-43.

Wahyudi, D. (2014). Dampak Penerapan Good Corporate Governance terhadap Kepatuhan Pajak $\begin{array}{lllll}\text { Perusahaan. } & \text { BPPK } & \text { Kemenkeu, } & 23 & \text { Mei }\end{array}$ http://www.bppk.kemenkeu.go.id/publikasi/artikel/167-artikel-pajak/19453-dampakpenerapan-good-corporate-governance-terhadap-kepatuhan-pajak-perusahaan (accessed September 30, 2017).

Zhang, H., Li, W., \& Jian, M. (2012). How Does State Ownership Affect Tax Avoidance? Evidence from China. Working paper. School of Accountancy, Singapore Management University. 